Article

\title{
Cyclometalated Ir(III) Complexes with Curcuminoid Ligands as Active Second-Order NLO Chromophores and Building Blocks for SHG Polymeric Films ${ }^{\dagger}$
}

\author{
Mattia Fontani ${ }^{1}$, Alessia Colombo ${ }^{1}$ (), Claudia Dragonetti ${ }^{1}$, Stefania Righetto ${ }^{1}$, \\ Dominique Roberto $^{1, *(D)}$ and Daniele Marinotto ${ }^{1,2}$ \\ 1 Dipartimento di Chimica e Centro CIMAINA dell'Università degli Studi di Milano, UdR-INSTM, Via C. \\ Golgi 19, I-20133 Milano, Italy; mattia.fontani@unimi.it (M.F.); alessia.colombo@unimi.it (A.C.); \\ claudia.dragonetti@unimi.it (C.D.); stefania.righetto@unimi.it (S.R.); daniele.marinotto@scitec.cnr.it (D.M.) \\ 2 CNR-SCITEC, Via C. Golgi 19, I-20133 Milano, Italy \\ * Correspondence: dominique.roberto@unimi.it; Tel.: +39-02-5031-4399 \\ $+\quad$ This paper is dedicated to Prof. Maddalena Pizzotti for her 70th birthday and for her important contribution \\ to the field of coordination compounds for optical and energy-related applications.
}

Received: 1 April 2020; Accepted: 13 May 2020; Published: 14 May 2020

check for updates

\begin{abstract}
The second-order nonlinear optical (NLO) properties of iridium(III) complexes having two cyclometalated 2-phenylpyridines and curcumin or tetrahydrocurcumin as ancillary ligand have been investigated both in solution and as guest in a polymeric organic matrix. In solution, these complexes are characterized by a significant second-order NLO response, as determined by the Electric Field Induced Second Harmonic (EFISH) technique, like the related complex with acetylacetonate. Whereas the low second-harmonic generation response of a composite film of [Ir(2-phenylpyridine) ${ }_{2}$ (acetylacetonate)] in polymethyl methacrylate was not stable and fell down to zero upon turning off the electric field. A good and stable response was obtained with a film based on the iridium(III) complex bearing two cyclometalated 2-phenylpyridines and curcumin.
\end{abstract}

Keywords: cyclometalated iridium(III) complexes; second-order nonlinear optics; EFISH; secondharmonic generation

\section{Introduction}

In the last thirty years, a lot of work has been devoted to molecular compounds with second-order nonlinear optical (NLO) properties, due to their potential in optoelectronic devices [1-3]. To have a high second-order NLO response, a molecule should not be centrosymmetric; it should have charge-transfer transitions of low energy, and there must be a big difference between the excited state dipole moment and the ground state dipole moment. Organic molecules with electron-donor (D) and electron-acceptor (A) fragments coupled via a $\pi$-conjugated polarizable moiety can have a respectable NLO response [4-9]. Coordination compounds also showed promise because they were characterized by low-energy ligand-to-metal (LM), metal-to-ligand (ML), ligand-to-ligand (LL), and intraligand (IL) charge transfer (CT) excited states. The intensity and energy of these transitions can be easily regulated by a judicious choice of the nature, oxidation state, and ligands of the metal center [10-27].

As determined by the Electric Field Induced Second Harmonic generation (EFISH) technique in solution [28-30], coordination complexes often reach a second-order NLO response larger than that of the prototypal Disperse Red One, trans- $\left.4,4^{\prime}-\mathrm{O}_{2} \mathrm{NC}_{6} \mathrm{H}_{4} \mathrm{~N}=\mathrm{NC}_{6} \mathrm{H}_{4} \mathrm{NEt}\left(\mathrm{CH}_{2} \mathrm{CH}_{2} \mathrm{OH}\right)\right]$, which has been used in electrooptic polymeric poled films [31]. Indeed, they can reach $\mu \beta$ values ( $\beta$ is the projection along the ground state dipole moment $(\mu)$ axis of the vectorial component of the tensor of the quadratic hyperpolarizability) superior to $500 \times 10^{-48} \mathrm{esu}$, making them competitive with respect to organic 
compounds and of interest for optoelectronic applications [10-27]. Among them, photoactive iridium complexes are very appealing not only for their attractive second-order NLO properties [27,32-37], but also because they find application in various fields, including in electroluminescent devices [38-41], in dye-sensitized solar cells [41-45], in sensing [41], as two-photon absorption reagents for high image resolution [46-50], as bioimaging probes [41,51-53], and in photodynamic therapy [54-57].

In the field of nonlinear optics, iridium complexes characterized by luminescent and NLO properties are fascinating as multifunctional molecular materials [58,59], as some of them have a versatile NLO redox-switching response $[60,61]$. In particular, those with two cyclometalated 2-phenylpyridine ligands (ppy) and a $\beta$-diketonate ancillary ligand, known for their luminescence and two-photon absorption properties [62], are of particular interest because they are characterized by a large second-order NLO response in solution [63]. The complex with acetylacetonate as an ancillary ligand is characterized by a $\mu \beta_{1.907}$ value, determined by the EFISH technique working with a 1.907 $\mu \mathrm{m}$ incident wavelength of $-910 \times 10^{-48}$ esu. A similar value was obtained when the acetylacetonate is functionalized with the electron acceptor 2,4-dinitrophenyl group, whereas a slightly higher absolute value was obtained with 1,3-diphenyl-1,3-propanedionate $\left(-1340 \times 10^{-48} \mathrm{esu}\right)$, which is in agreement with the higher polarizability of the phenyl compared to the methyl substituent [63]. A Sum-Over-States Time-Dependent Density Functional Theory (SOS-TDDFT) investigation showed that the large NLO response of these complexes is principally caused by $\pi-\pi^{*}$ intraligand charge transfer transitions involving the cyclometalated 2-phenylpyridines, while transitions involving the $\beta$-diketonate ligand do not contribute meaningfully [63]. Remarkably, the second-order NLO response of the free 2-phenylpyridine is very low, putting in evidence the important role of cyclometalation, and therefore of iridium, in increasing the quadratic hyperpolarizability. In order to understand if an appropriate functionalization of the 2-phenylpyridine ligands could improve the second-order NLO activity, a series of iridium(III) acetylacetonate compounds with various cyclometalated 4-styryl-2-phenylpyridines substituted with donor $\left(\mathrm{NEt}_{2}, \mathrm{OMe}\right)$ or acceptor $\left(\mathrm{NO}_{2}\right)$ substituents was investigated [64]. The best $\mu \beta_{1.907}$ value, obtained with the 4-styryl-2-phenylpyridine bearing the nitro group, was slightly lower than that of the complex with the simple 2-phenylpyridine [64]. Thus, the simple luminescent iridium(III) complex with two cyclometalated 2-phenylpyridine ligands and acetylacetonate as an ancillary ligand appeared as a particularly appealing tool for NLO applications. However, various attempts to prepare stable NLO-active hybrid polymeric films based on this complex failed.

These observations prompted us to investigate the second-order NLO properties of two iridium(III) complexes with two cyclometalated 2-phenylpyridines and curcumin (complex Ir1) or tetrahydrocurcumin (complex Ir2) as an ancillary ligand (Figure 1), recently studied for their luminescence and photoactivated anticancer activity [54]. Both show large $\mu \beta_{1.907}$ absolute values, and, remarkably, complex Ir1 can be used to prepare hybrid polymeric films with a good second harmonic generation response. The results of this investigation are presented in this report.

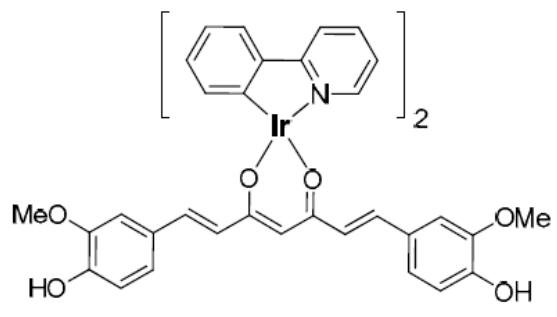

Ir1

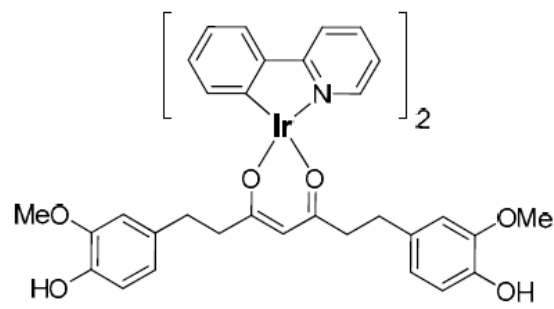

Ir2

Figure 1. Investigated iridium (III) complexes.

\section{Results and Discussion}

The cyclometalated curcuminoid iridium(III) complexes are easily prepared in two steps, as shown in Scheme 1: 
(i) Preparation of the chloro-bridge dimer $\left[\operatorname{Ir}(\mathrm{ppy})_{2} \mathrm{Cl}_{2}\right.$ (ppy = cyclometalated 2-phenylpyridine) from $\mathrm{IrCl}_{3} \cdot 3 \mathrm{H}_{2} \mathrm{O}$ [65];

(ii) Bridge splitting reaction with the deprotonated curcumin or tetrahydrocurcumin [53].

i)

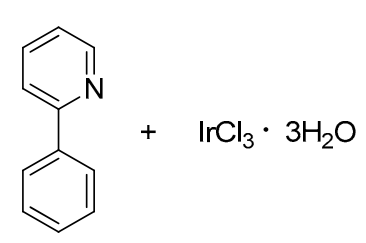

ppy
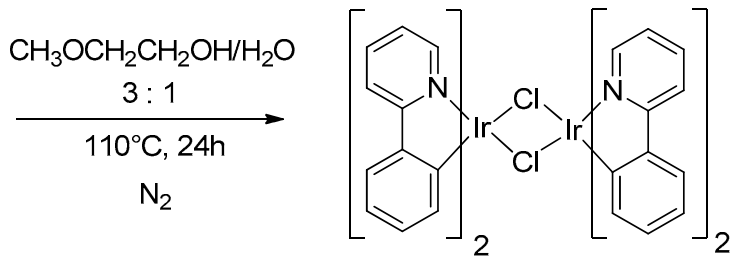

$\left[\mathrm{Ir}(\mathrm{ppy})_{2} \mathrm{Cl}\right]_{2}(71 \%)$

ii)<smiles>COc1cc(/C=C/C(=O)CC(=O)/C=C/c2ccc(O)c(OC)c2)ccc1O</smiles><smiles>COc1cc(CCC(=O)CC(=O)CCc2ccc(O)c(OC)c2)ccc1O</smiles><smiles>O[I-](O)(c1ccccc1)n1cccc1-c1ccccc1</smiles>

$\left[\mathrm{Ir}(\mathrm{ppy})_{2} \mathrm{Cl}\right]_{2}$<smiles>[H][Y10]([H])(N)CC</smiles><smiles>COc1cc(/C=C/C(=O)/C=C/C(=O)/C=C/c2ccc(O)c(OC)c2)ccc1O</smiles>
$\underset{\mathrm{MeOH}, 0^{\circ} \mathrm{C} 1 \mathrm{~h}}{\stackrel{\mathrm{MeONa}}{\longrightarrow}}$<smiles>COc1ccc(C)cc1O</smiles><smiles>COc1ccccc1O</smiles>

$(60 \%)$<smiles>Ic1ccccc1</smiles><smiles>COc1cc(CCC2=CC(CCc3ccc(O)c(OC)c3)O[I-](c3ccccc3)(I3c4ccccc4-c4cccn43)C2)ccc1O</smiles>

$(55 \%)$

1a (not isolated) 2a $\left[\mathrm{Ir}(\mathrm{ppy})_{2} \mathrm{Cll}_{2} /\right.$

Scheme 1. Preparation of cyclometalated curcuminoid iridium(III) complexes.

The pure complexes, obtained by recrystallization, were well characterized (see Section 3).

The Electric Field Induced Second Harmonic generation (EFISH) method was used to determine the second-order nonlinear optical (NLO) properties in chloroform solution $\left(10^{-3} \mathrm{M}\right)$ of complexes Ir1 and Ir2. It is known that this method [28-30] allows the study of the molecular second-order NLO response, by using Equation (1):

$$
\gamma_{\mathrm{EFISH}}=\left(\mu \beta_{\lambda} / 5 \mathrm{kT}\right)+\gamma(-2 \omega ; \omega, \omega, 0),
$$

where $\beta_{\lambda} / 5 \mathrm{kT}$ characterizes the dipolar orientational impact on the molecular nonlinearity, while $\gamma$ $(-2 \omega ; \omega, \omega, 0)$ describes the third order polarizability, which is an electronic cubic contribution to $\gamma_{\text {EFISH }}$. The latter is commonly ignored when studying the second-order NLO properties of dipolar compounds. $\mu$ is the ground state dipole moment. $\beta_{\lambda}$ describes the projection along the $\mu$ axis of 
$\beta_{V E C}$, which is the vectorial element of the quadratic hyperpolarizability tensor when working with an incident wavelength, $\lambda$. Extrapolation to zero frequency $\left(v_{\Lambda}=0.0 \mathrm{eV} ; \lambda=\infty\right)$ permits the determination of $\mu \beta_{0}$ where $\beta_{0}$ is the static quadratic hyperpolarizability, a useful figure of merit to compare the second-order NLO properties of molecules. This value can be obtained by using Equation (2):

$$
\mu \beta_{0}=\mu \beta_{\lambda}\left[1-\left(2 \lambda_{\max } / \lambda\right)^{2}\right]\left[1-\left(\lambda_{\max } / \lambda\right)^{2}\right],
$$

where $\beta_{\lambda}$ is the quadratic hyperpolarizability value at the incident wavelength, $\lambda$, and $\lambda_{\max }$ is the absorption wavelength of the major charge transfer transition considered. A molecule having a $\mu \beta_{0}$ higher than that of Disperse Red One $\left(450 \times 10^{-48} \mathrm{esu}\right)$, which was used in electrooptic polymeric poled films [31], is commonly considered of interest for second-order NLO applications.

When determining the quadratic hyperpolarizability, it is important to avoid resonance enhancements that would lead to an overestimation of the value. Therefore, it is essential to choose an incident wavelength with a second harmonic far from the absorption wavelengths of the investigated compound. In order to study complexes Ir1 and Ir2, we worked with a $1.907 \mu \mathrm{m}$ incident wavelength achieved by Raman-shifting the $1.064 \mu \mathrm{m}$ wavelength obtained from a Q-switched, mode-locked Nd:YAG laser.

We found that both cyclometalated curcuminoid iridium(III) complexes have a negative value of $\mu \beta_{1.907}$, like other $\beta$-diketonate cyclometalated iridium(III) complexes [63,64], showing that there is a negative value of $\Delta \mu_{\mathrm{eg}}$ (difference of the dipole moment in the excited state and in the ground state) upon excitation, following the "two-level" model $[66,67]$.

The $\mu \beta_{1.907}$ value of complex Ir1 is $-1050 \times 10^{-48}$ esu, corresponding to a $\mu \beta_{0}$ value of $-747 \times$ $10^{-48}$ esu calculated by using Equation (2). The low energy charge transfer absorption band (470 $\mathrm{nm}$ [54]) much higher than that of Disperse Red One [31] and slightly larger than that of the related complex with acetylacetonate instead of the curcumin ligand. The use of tetrahydrocurcumin as an ancillary ligand (complex Ir2) affords a similar second-order NLO response $\left(\mu \beta_{1.907}=-930 \times 10^{-48}\right.$ esu; $\mu \beta_{0}=-661 \times 10^{-48}$ esu by using Equation (2) and $\lambda_{\max }=470 \mathrm{~nm}$ [54]). This is a significant result, because compounds showing both luminescent and nonlinear optical properties are of growing interest as multifunctional molecular materials for optoelectronics [68-77].

As a further step, we were curious to study the second-order NLO properties of a composite polymethyl methacrylate (PMMA) polymeric film based on complex Ir1. The composite film was prepared by spin coating a dichloromethane solution of complex Ir1 and PMMA (5\% wt complex Ir1/PMMA) on ordinary glass substrate. The corona wire poling dynamic of the second harmonic generation (SHG) is shown in Figure 2a.

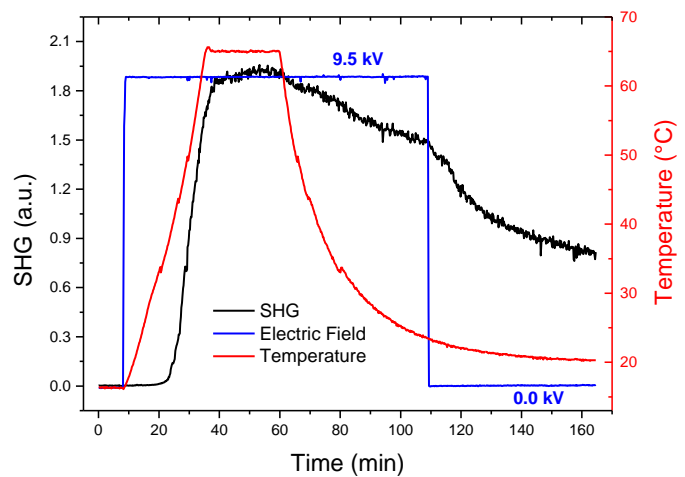

(a)

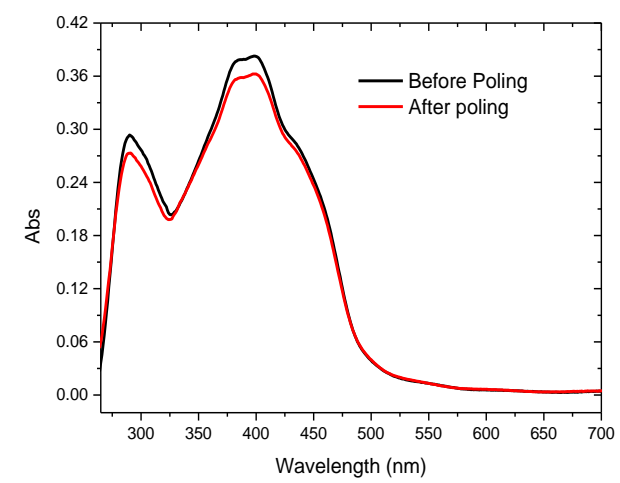

(b)

Figure 2. (a) Second harmonic generation (SHG) plot of composite films containing $5 \%$ (wt) of complex Ir1 in a PMMA matrix. (b) Absorbance spectrum before (black line) and after (red line) poling. 
The SHG signal is insignificant at room temperature, but it rapidly intensifies upon heating in the presence of the electric field $(9.5 \mathrm{kV})$ under nitrogen, due to the diminution of the polymeric film viscosity which permits an easier orientation of the dipolar molecules of complex Ir1. The signal reaches a plateau at $65{ }^{\circ} \mathrm{C}$. It was halved after cooling to room temperature and switching off the electric field. Remarkably, contrarily to what happened with the composite PMMA film containing [Ir(ppy) ${ }_{2}$ (acetylacetonate)] [64], the SHG signal does not fall to zero, showing that the curcumin ligand is able to stabilize the orientation of the NLO-active $\operatorname{Ir}(\mathrm{III})$ complex in the polymeric PMMA matrix.

The electronic absorption spectra of the composite PMMA film containing complex Ir1, recorded before and after the poling process, are shown in Figure $2 b$. There was a small decrease of the intensity of the main absorption peaks after poling, probably due to a dichroism effect caused by the reorientation of dipolar molecules [78], whereas no significant Stark shift was observed.

The second order NLO response, $\chi^{(2)}$ 33, was determined by using the Maker fringes method [79-83]. A value of $2.82 \mathrm{pm} / \mathrm{V}$ was obtained, a remarkable response for such a simple complex. These results put in evidence that substitution of acetylacetonate by a curcuminoid ligand is a simple avenue to stabilize the orientation of the NLO-active Ir(III) complex in the polymeric PMMA matrix, allowing a good SHG response.

\section{Materials and Methods}

\subsection{Synthesis of $\left[\operatorname{Ir}(p p y)_{2}(\mu-C l)\right]_{2}$}

2-Phenylpyridine $(506 \mu \mathrm{L}, 3.03 \mathrm{mmol})$ was added to a solution of $\mathrm{IrCl}_{3} \cdot 3 \mathrm{H}_{2} \mathrm{O}(360 \mathrm{mg}, 1.01$ $\mathrm{mmol})$ in 2-methoxyethanol/water $(60 \mathrm{~mL} / 20 \mathrm{~mL})$ under nitrogen. After stirring under reflux for $24 \mathrm{~h}$, the reaction mixture was cooled to room temperature. The precipitated yellow powder was filtered, washed first with methanol, and then with diethyl ether. The pure product $(576 \mathrm{mg})$ was obtained as a yellow solid by recrystallization from dichloromethane and pentane. Yield $=71 \%$.

${ }^{1} \mathrm{HNMR}(400 \mathrm{MHz}, \mathrm{DMSO}): \delta(\mathrm{ppm}) 9.81(\mathrm{~d}, J=8.1 \mathrm{~Hz}, 2 \mathrm{H}), 9.55(\mathrm{~d}, J=8.1 \mathrm{~Hz}, 2 \mathrm{H}), 8.26(\mathrm{~d}, J=$ $8.1 \mathrm{~Hz}, 2 \mathrm{H}), 8.18(\mathrm{~d}, J=8.0 \mathrm{~Hz}, 2 \mathrm{H}), 8.12(\mathrm{t}, J=8.0 \mathrm{~Hz}, 2 \mathrm{H}), 8.01(\mathrm{t}, J=8.1 \mathrm{~Hz}, 2 \mathrm{H}), 7.79(\mathrm{~d}, J=8.0 \mathrm{~Hz}$, $2 \mathrm{H}), 7.73(\mathrm{~d}, J=8.0 \mathrm{~Hz}, 2 \mathrm{H}), 7.57(\mathrm{t}, J=8.0 \mathrm{~Hz}, 2 \mathrm{H}), 7.45(\mathrm{t}, J=8.0 \mathrm{~Hz}, 2 \mathrm{H}), 6.90(\mathrm{t}, J=8.0 \mathrm{~Hz}, 2 \mathrm{H}), 6.86$ $(\mathrm{t}, J=8.0 \mathrm{~Hz}, 2 \mathrm{H}), 6.77(\mathrm{t}, J=8.0 \mathrm{~Hz}, 2 \mathrm{H}), 6.69(\mathrm{t}, J=8.0 \mathrm{~Hz}, 2 \mathrm{H}), 6.27(\mathrm{~d}, J=8.1 \mathrm{~Hz}, 2 \mathrm{H})$, and $5.67(\mathrm{~d}, J$ $=8.1 \mathrm{~Hz}, 2 \mathrm{H})$.

\subsection{Synthesis of Complex $\mathbf{I r} \mathbf{1}$}

$\mathrm{NaOMe}(40 \mathrm{mg}, 0.74 \mathrm{mmol})$ was added to a solution of curcumin $(274 \mathrm{mg}, 0.74 \mathrm{mmol})$ in methanol $(15 \mathrm{~mL})$ at $0^{\circ} \mathrm{C}$. After stirring for $1 \mathrm{~h},\left[\operatorname{Ir}(\mathrm{ppy})_{2}(\mu-\mathrm{Cl})\right]_{2}(398 \mathrm{mg}, 0.37 \mathrm{mmol})$ was added, affording an orange solution. After stirring for $24 \mathrm{~h}$ under reflux, the precipitate was filtered and then crystalized from dichloromethane and diethylether affording $392 \mathrm{mg}$ of pure product as an orange powder; Yield $=60 \%$ (Scheme 2$)$.

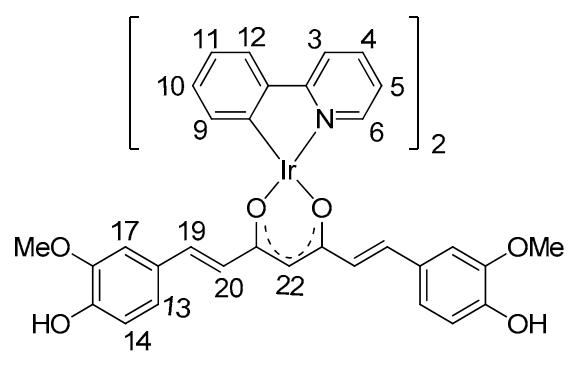

Scheme 2. Numeration for NMR of Ir1.

${ }^{1} \mathrm{H}$ NMR (600 MHz, CD 3 CN, $)$ ppm: $8.58\left(\mathrm{~d}, J=5.6 \mathrm{~Hz}, 2 \mathrm{H}, \mathrm{H}_{6}\right), 8.02\left(\mathrm{~d}, J=8.2 \mathrm{~Hz}, 2 \mathrm{H}, \mathrm{H}_{3}\right), 7.86$ $\left(\mathrm{t}, J=7.5 \mathrm{~Hz}, 2 \mathrm{H}, \mathrm{H}_{4}\right), 7.68\left(\mathrm{~d}, J=7.7 \mathrm{~Hz}, 2 \mathrm{H}, \mathrm{H}_{12}\right), 7.27\left(\mathrm{~d}, J=6.1 \mathrm{~Hz}, 2 \mathrm{H}, \mathrm{H}_{5}\right), 7.17(\mathrm{~d}, J=15.7 \mathrm{~Hz}, 2 \mathrm{H}$, $\left.\mathrm{H}_{19}\right), 7.12\left(\mathrm{~d}, J=1.6 \mathrm{~Hz}, 2 \mathrm{H}, \mathrm{H}_{17}\right), 6.99\left(\mathrm{dd}, J_{1}=8.2 \mathrm{~Hz}, J_{2}=1.6 \mathrm{~Hz} 2 \mathrm{H}, \mathrm{H}_{14}\right), 6.86\left(\mathrm{t}, J=7.3 \mathrm{~Hz}, 2 \mathrm{H}, \mathrm{H}_{11}\right)$, 
$6.78\left(\mathrm{~d}, J=8.2 \mathrm{~Hz}, 2 \mathrm{H}, \mathrm{H}_{13}\right), 6.72\left(\mathrm{t}, J=7.3 \mathrm{~Hz}, 2 \mathrm{H}, \mathrm{H}_{10}\right), 6.61\left(\mathrm{~d}, J=15.7 \mathrm{~Hz}, 2 \mathrm{H}, \mathrm{H}_{20}\right), 6.25(\mathrm{~d}, J=7.5$ $\left.\mathrm{Hz}, 2 \mathrm{H}, \mathrm{H}_{9}\right), 5.75\left(\mathrm{~s}, 1 \mathrm{H}, \mathrm{H}_{22}\right)$, and $3.87\left(\mathrm{~s}, 6 \mathrm{H}, \mathrm{OCH}_{3}\right) .{ }^{13} \mathrm{C} \mathrm{NMR}\left(150 \mathrm{MHz}, \mathrm{CD}_{3} \mathrm{CN}, \delta\right)$ ppm: 176.8 $\left(C^{21}\right), 168.2\left(C^{2}\right), 148.1\left(C^{6}\right), 147.8,147.6,147.6\left(C_{16}, C_{8}, C_{15}\right), 145.4\left(C^{7}\right), 137.8\left(C^{4}\right), 136.1\left(C^{20}\right), 133.0$ $\left(C^{9}\right), 128.7\left(C^{10}\right), 128.4\left(C^{18}\right), 128.0\left(C^{19}\right), 123.9\left(C^{12}\right), 122.2\left(C^{5}\right), 121.7\left(C^{14}\right), 120.8\left(C^{11}\right), 118.7\left(C^{3}\right), 115.0$ $\left(\mathrm{C}^{13}\right), 110.0\left(\mathrm{C}^{17}\right), 103.1\left(\mathrm{C}^{22}\right)$, and $55.7\left(\mathrm{OCH}_{3}\right)$. Anal. Calcd. (\%) for $\mathrm{C}_{44} \mathrm{H}_{39} \mathrm{IrN}_{2} \mathrm{O}_{6}: \mathrm{C}, 59.78 ; \mathrm{H}, 4.45$; and N, 3.17. Found: C 59.85, H 4.46, and N 3.16.

\subsection{Synthesis of Complex Ir2}

$\mathrm{NaOMe}(45 \mathrm{mg}, 0.83 \mathrm{mmol})$ was added to a solution of tetrahydrocurcumin $(310 \mathrm{mg}, 0.83 \mathrm{mmol})$ in methanol $(21 \mathrm{~mL})$ at $0{ }^{\circ} \mathrm{C}$. After stirring for $1 \mathrm{~h},\left[\operatorname{Ir}(\mathrm{ppy})_{2}(\mu-\mathrm{Cl})\right]_{2}(420 \mathrm{mg}, 0.4 \mathrm{mmol})$ was added, affording a yellow solution. After stirring for $24 \mathrm{~h}$ under reflux, the precipitate was filtered and then crystalized from dichloromethane and diethylether, affording $405 \mathrm{mg}$ of pure product as a dark yellow powder; Yield $=55 \%$ (Scheme 3 ).

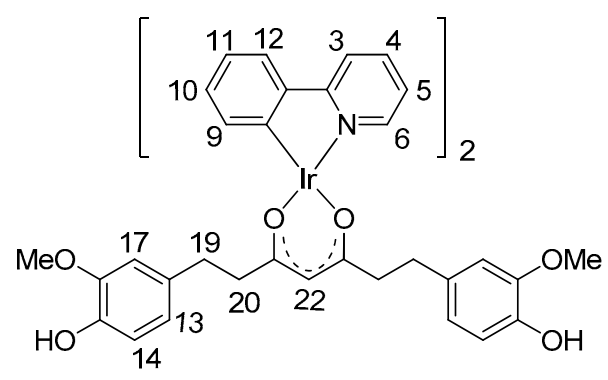

Scheme 3. Numeration for NMR of Ir2.

${ }^{1} \mathrm{H}$ NMR (600 MHz, CD 3 CN, $\delta$ ) ppm: $8.24\left(\mathrm{~d}, J=4.98 \mathrm{~Hz}, 2 \mathrm{H}, \mathrm{H}_{6}\right), 8.00\left(\mathrm{~d}, J=8.1 \mathrm{~Hz}, 2 \mathrm{H}, \mathrm{H}_{3}\right)$, $7.86\left(\mathrm{t}, J=8.1 \mathrm{~Hz}, 2 \mathrm{H}, \mathrm{H}_{4}\right), 7.64\left(\mathrm{~d}, J=5.2 \mathrm{~Hz}, 2 \mathrm{H}, \mathrm{H}_{12}\right), 7.16\left(\mathrm{t}, J=6.54 \mathrm{~Hz}, 2 \mathrm{H}, \mathrm{H}_{5}\right), 6.83(\mathrm{t}, J=7.4$ $\left.\mathrm{Hz}, 2 \mathrm{H}, \mathrm{H}_{11}\right), 6.70\left(\mathrm{~s}, 2 \mathrm{H}, \mathrm{H}_{17}\right), 6.67\left(\mathrm{t}, J=7.4 \mathrm{~Hz}, 2 \mathrm{H}, \mathrm{H}_{10}\right), 6.61\left(\mathrm{~d}, J=8.0 \mathrm{~Hz}, 2 \mathrm{H}, \mathrm{H}_{14}\right), 6.39(\mathrm{t}, J=8.0$ $\left.\mathrm{Hz}, 2 \mathrm{H}, \mathrm{H}^{13}\right), 6.17\left(\mathrm{~d}, J=7.4 \mathrm{~Hz}, 2 \mathrm{H}, \mathrm{H}_{9}\right), 5.34\left(\mathrm{~s}, 1 \mathrm{H}, \mathrm{H}_{22}\right), 3.77\left(\mathrm{~s}, 6 \mathrm{H}, \mathrm{OCH}_{3}\right), 2.63-2.55\left(\mathrm{~m}, 4 \mathrm{H}, \mathrm{H}_{19}\right)$, 2.37-2.32 (m, 2H, $\left.\mathrm{H}_{20}\right)$, and 2.27-2.21 (m, 2H, $\left.\mathrm{H}_{20}\right) .{ }^{13} \mathrm{C} \mathrm{NMR}\left(150 \mathrm{MHz}, \mathrm{CD}_{3} \mathrm{CN}, \delta\right)$ ppm: $186.8\left(\mathrm{C}^{21}\right)$, 168.0 $\left(C^{2}\right), 148.2\left(C^{6}\right), 147.8,147.6,147.6\left(C^{16}, C^{8}, C^{15}\right), 144.1\left(C^{18}\right), 145.4\left(C^{7}\right), 137.6\left(C^{4}\right), 133.1\left(C^{9}\right)$, $128.6\left(C^{10}\right), 123.8\left(C^{12}\right), 122.1\left(C^{5}\right), 120.7\left(C^{13}\right), 120.7\left(C^{11}\right), 118.6\left(C^{3}\right), 114.4\left(C^{14}\right), 111.9\left(C^{17}\right), 99.8\left(C^{22}\right)$, $55.6\left(\mathrm{OCH}_{3}\right), 42.8\left(\mathrm{C}^{20}\right)$, and $31.9\left(\mathrm{C}^{19}\right)$. Anal. Calcd. (\%) for $\mathrm{C}_{44} \mathrm{H}_{43} \mathrm{IrN}_{2} \mathrm{O}_{6}: \mathrm{C}, 59.50 ; \mathrm{H}, 4.88$; and N, 3.15. Found: C 59.68, H 4.91, and N 3.16.

\subsection{Measurement of the Second-Order NLO Properties in Solution}

EFISH measurements were carried out by using a non-resonant incident wavelength of 1.907 $\mu \mathrm{m}$, achieved by Raman-shifting the fundamental $1.064 \mu \mathrm{m}$ wavelength given by a Q-switched, mode-locked Nd:YAG laser (from Atalaser). Complexes Ir1 and Ir2 were dissolved in chloroform at a concentration of $10^{-3} \mathrm{M}$. The reported $\mu \beta_{1.907}$ values are the mean values of 16 measurements performed on the same sample.

\subsection{Preparation of Composite Films of Complex Ir1 in PMMA and Related SHG Measurements}

Composite films were prepared by spin coating a dichloromethane solution $(3.5 \mathrm{~mL})$ of complex Ir1 (20 mg) and PMMA (400 mg) on ordinary glass substrates (thickness $1 \mathrm{~mm}$ ), previously cleaned with water/acetone. Electronic absorption spectra of the composite films of complex Ir1 in PMMA were obtained with a UV-3600i Plus UV-VIS-NIR Spectrophotometer (Shimadzu Italia S.r.l., Milan, Italy). Second Harmonic Generation (SHG) measurements were carried out with a Quanta System Giant G790-20 laser with a $1.064 \mu \mathrm{m}$ wavelength, a $7 \mathrm{~ns}$ pulse, and a $20 \mathrm{~Hz}$ repetition rate (Quanta System SpA, Samarate, Italy). The corona poling process was performed inside a dry box under $\mathrm{N}_{2}$, as previously reported [80-83]. The setup for Maker fringe measurements was similar to that 
previously described [80-83]. The SHG signal was normalized with a calibrated quartz crystal wafer (X-cut, $1 \mathrm{~mm}$ thick, $\mathrm{d}_{11}=0.46 \mathrm{pm} / \mathrm{V}$ ).

\section{Conclusions}

In conclusion, this work shows the significant second-order nonlinear optical properties in solutions of iridium(III) complexes with two cyclometalated 2-phenylpyridines, and curcumin or tetrahydrocurcumin as ancillary ligand. Notably, it unveiled the great potential of curcuminoid ligands for the preparation of NLO-active hybrid polymeric films based on metal complexes. As a matter of fact, a common drawback of NLO-active hybrid films, containing a metal complex with second-order NLO properties dispersed in a polymeric matrix and oriented by corona poling, is the progressive fading of the NLO signal with time due to the loss of orientation of the guest molecules in the host polymer once the electric field is removed. It turned out that, whereas the low second-harmonic generation response of a composite film of [ $\operatorname{Ir}\left(2\right.$-phenylpyridine) ${ }_{2}$ (acetylacetonate)] in polymethyl methacrylate is not stable and fell down to zero upon turning off the electric field, a good and stable response was obtained with a film based on the iridium(III) complex with two cyclometalated 2-phenylpyridines and curcumin. This result is of particular relevance because it reveals the key role of the curcumin ligand in stabilizing the orientation of the NLO-active Ir(III) complex in the polymeric matrix. Clearly, the use of the curcumin ligand appears as an interesting way to design metal complexes for the preparation of hybrid films with a good and stable second-order nonlinear optical response.

Author Contributions: Conceptualization, A.C., C.D., and D.R.; Data curation, A.C. and S.R.; Funding acquisition, C.D. and D.R.; Investigation, S.R. and D.M.; Methodology, M.F.; Software, A.C. and D.M.; Supervision, C.D.; Writing—original draft, D.R.; Writing—review \& editing, M.F., A.C., C.D., S.R., D.R., and D.M. All authors have read and agreed to the published version of the manuscript.

Funding: This research was funded by Università degli Studi di Milano, grant number PSR 2019-Linea 2 Azione A-PSR2019_DIP_005_PI_CDRAG “Coordination complexes and organic-inorganic hybrid materials for photonics and optoelectronics", and by National Interuniversity Consortium of Materials Science and Technology, grant number INSTMMI012.

Conflicts of Interest: The authors declare no conflict of interest.

\section{References}

1. Prasad, N.P.; Williams, D.J. Introduction to Nonlinear Optical Effects in molecules and Polymers; Wiley: Hoboken, NJ, USA, 1991.

2. Zyss, J. Molecular Nonlinear Optics: Materials, Physics and Devices; Academic Press: Boston, MA, USA, 1994.

3. Optoelectronic Properties of Inorganic Compounds; Roundhill, D.M.; Fackler, J.P., Jr. (Eds.) Plenum Press: New York, NY, USA, 1999.

4. Kanis, D.R.; Ratner, M.A.; Marks, T.J. Optical nonlinearities of conjugated molecules. Stilbene derivatives and highly polar aromatic compounds. Chem. Rev. 1994, 67, 195-242. [CrossRef]

5. Cheng, L.T.; Tam, W.; Stevenson, S.H.; Meredith, G.R.; Rikken, G.; Marder, S.R. Experimental investigations of organic molecular nonlinear optical polarizabilities. 1. Methods and results on benzene and stilbene derivatives. J. Phys. Chem. 1991, 95, 10631-10643. [CrossRef]

6. Cheng, L.T.; Tam, W.; Marder, S.R.; Stiegman, A.E.; Rikken, G.; Spangler, C.W. Stronger acceptors can diminish nonlinear optical response in simple donor-acceptor polyenes. J. Phys. Chem. 1991, 95, 10643-10652. [CrossRef]

7. Beverina, L.; Ruffo, R.; Patriarca, G.; De Angelis, F.; Roberto, D.; Righetto, S.; Ugo, R.; Pagani, G.A. Second harmonic generation in nonsymmetrical squaraines: Tuning of the directional charge transfer character in highly delocalized dyes. J. Mater. Chem. 2009, 19, 8190-8197. [CrossRef]

8. Dalton, L.R.; Sullivan, P.A.; Bale, D.H. Electric field poled organic electro-optic materials: State of the art and future prospects. Chem. Rev. 2010, 110, 25-55. [CrossRef] 
9. Cariati, E.; Dragonetti, C.; Lucenti, E.; Nisic, F.; Righetto, S.; Roberto, D.; Tordin, E. An acido-triggered reversible luminescent and nonlinear optical switch based on a substituted styrylpyridine: EFISH measurements as an unusual method to reveal a protonation-deprotonation NLO contrast. Chem. Commun. 2014, 50, 1608-1610. [CrossRef]

10. Heck, J.; Dabek, S.; Meyer-Friedrichsen, T.; Wong, H. Mono- and dinuclear sesquifulvalene complexes, organometallic materials with large nonlinear optical properties. Coord. Chem. Rev. 1999, 190-192, 1217-1254. [CrossRef]

11. Le Bozec, H.; Renouard, T. Dipolar and non-dipolar pyridine and bipyridine metal complexes for nonlinear optics. Eur. J. Inorg. Chem. 2000, 2, 229-239. [CrossRef]

12. Di Bella, S. Second-order nonlinear optical properties of transition metal complexes. Chem. Soc. Rev. 2001, 30, 355-366. [CrossRef]

13. Pizzotti, M.; Ugo, R.; Roberto, D.; Bruni, S.; Fantucci, P.C.; Rovizzi, C. Organometallic counterparts of push-pull aromatic chromophores for nonlinear optics: Push-pull heteronuclear bimetallic complexes with pyrazine and trans-1,2-Bis(4-pyridyl)ethylene as Linkers. Organometallics 2002, 21, 5830-5840. [CrossRef]

14. Tessore, F.; Roberto, D.; Ugo, R.; Mussini, P.; Quici, S.; Ledoux-Rak, I.; Zyss, J. Large, Concentration-dependent enhancement of the quadratic hyperpolarizability of $\left[\mathrm{Zn}\left(\mathrm{CH}_{3} \mathrm{CO}_{2}\right)_{2}(\mathrm{~L})_{2}\right]$ in $\mathrm{CHCl}_{3}$ on substitution of acetate by triflate. Angew. Chem. Int. Ed. 2003, 42, 456-459. [CrossRef]

15. Powell, C.E.; Humphrey, M.G. Nonlinear optical properties of transition metal acetylides and their derivatives. Coord. Chem. Rev. 2004, 248, 725-756. [CrossRef]

16. Coe, B.J. Nonlinear Optical Properties of Metal Complexes. In Comprehensive Coordination Chemistry II; McCleverty, J.A., Meyer, T.J., Eds.; Elsevier Pergamon: Oxford, UK, 2004; Volume 9, pp. 621-687.

17. Maury, O.; Le Bozec, H. Molecular engineering of octupolar NLO molecules and materials based on bipyridyl metal complexes. Acc. Chem. Res. 2005, 38, 691-704. [CrossRef]

18. Cariati, E.; Pizzotti, M.; Roberto, D.; Tessore, F.; Ugo, R. Coordination and organometallic compounds and inorganic-organic hybrid cristalline materials for second-order non-linear optics. Coord. Chem. Rev. 2006, 250, 1210-1233. [CrossRef]

19. Coe, B.J. Switchable nonlinear optical metallochromophores with pyridinium electron acceptor groups. Acc. Chem. Res. 2006, 39, 383-393. [CrossRef]

20. Morrall, J.P.; Dalton, G.T.; Humphrey, M.G.; Samoc, M. Organotransition metal complexes for nonlinear optics. Adv. Organomet. Chem. 2007, 55, 61-136.

21. Di Bella, S.; Dragonetti, C.; Pizzotti, M.; Roberto, D.; Tessore, F.; Ugo, R. Coordination and organometallic complexes as second-order nonlinear optical materials. In Molecular Organometallic Material for Optics; Bozec, H., Guerchais, V., Eds.; Springer: Heidelberg, Germany, 2010; pp. 1-55.

22. Valore, A.; Balordi, M.; Colombo, A.; Dragonetti, C.; Righetto, S.; Roberto, D.; Ugo, R.; Benincori, T.; Rampinini, G.; Sannicolò, F.; et al. Novel ruthenium(II) complexes with substituted 1,10-phenanthroline or 4,5-diazafluorene linked to a fullerene as highly active second order NLO chromophores. Dalton Trans. 2010, 39, 10314-10318. [CrossRef]

23. Boixel, J.; Guerchais, V.; Le Bozec, H.; Chantzis, A.; Jacquemin, D.; Colombo, A.; Dragonetti, C.; Marinotto, D.; Roberto, D. Sequential double second-order nonlinear optical switch by an acido-triggered photochromic cyclometallated platinum(II) complex. Chem. Commun. 2015, 51, 7805-7808. [CrossRef]

24. Tessore, F.; Orbelli Biroli, A.; Di Carlo, G.; Pizzotti, M. Porphyrins for second order nonlinear optics (NLO): An intriguing history. Inorganics 2018, 6, 81. [CrossRef]

25. Di Bella, S.; Colombo, A.; Dragonetti, C.; Righetto, S.; Roberto, D. Zinc(II) as a versatile template for the preparation of fascinating dipolar and octupolar second-order nonlinear optical molecular materials. Inorganics 2018, 6, 133. [CrossRef]

26. Durand, R.J.; Gauthier, S.; Achelle, S.; Groizard, T.; Kahlal, S.; Saillard, J.Y.; Barsella, A.; Le Poul, N.; Robin Le Guen, F. Push-pull D- $\pi$-Ru- $\pi$-A chromophores: Synthesis and electrochemical, photophysical and second-order nonlinear optical properties. Dalton Trans. 2018, 47, 3965-3975. [CrossRef] [PubMed]

27. Colombo, A.; Dragonetti, C.; Guerchais, V.; Hierlinger, C.; Zysman-Colman, E.; Roberto, D. A trip in the nonlinear optical properties of iridium complexes. Coord. Chem. Rev. 2020, 414, 213293. [CrossRef]

28. Ledoux, I.; Zyss, J. Influence of the molecular environment in solution measurements of the Second-order optical susceptibility for urea and derivatives. Chem. Phys. 1982, 73, 203-213. [CrossRef] 
29. Levine, B.F.; Bethea, C.G. Molecular hyperpolarizabilities determined from conjugated and nonconjugated organic liquids. Appl. Phys. Lett. 1974, 24, 445-447. [CrossRef]

30. Levine, B.F.; Bethea, C.G. Second and third order hyperpolarizabilities of organic molecules. J. Chem. Phys. 1975, 63, 2666-2682. [CrossRef]

31. Singer, K.D.; Sohn, J.E.; King, L.A.; Gordon, H.M.; Katz, H.E.; Dirk, C.W. Second-order nonlinear-optical properties of donor- and acceptor-substituted aromatic compounds. J. Opt. Soc. Am. B 1989, 6, 1339-1350. [CrossRef]

32. Roberto, D.; Tessore, F.; Ugo, R.; Bruni, S.; Manfredi, A.; Quici, S. Terpyridine Zn(II), Ru(III) and Ir(III) complexes as new asymmetric chromophores for nonlinear optics: First evidence for a shift from positive to negative value of the quadratic hyperpolarizability of a ligand carrying an electron donor substituent upon coordination to different metal centres. Chem. Commun. 2002, 846-847. [CrossRef]

33. Dragonetti, C.; Righetto, S.; Roberto, D.; Ugo, R.; Valore, A.; Demartin, F.; De Angelis, F.; Sgamellotti, A.; Fantacci, S. The role of 5-R-1,10-phenanthroline $\left(\mathrm{R}=\mathrm{CH}_{3}, \mathrm{NO}_{2}\right)$ on the emission properties and second-order NLO response of cationic Ir(III) organometallic chromophores. Inorg. Chim. Acta 2008, 361, 4070-4076. [CrossRef]

34. Valore, A.; Cariati, E.; Dragonetti, C.; Righetto, S.; Roberto, D.; Ugo, R.; De Angelis, F.; Fantacci, S.; Sgamellotti, A.; Macchioni, A.; et al. Cyclometalated Ir ${ }^{\mathrm{III}}$ complexes with substituted 1,10-phenanthrolines: A new class of efficient cationic organometallic second-order NLO chromophores. Chem. Eur. J. 2010, 16, 4814-4825. [CrossRef]

35. Dragonetti, C.; Valore, A.; Colombo, A.; Righetto, S.; Rampinini, G.; Colombo, F.; Rocchigiani, L.; Macchioni, A. An investigation on the second-order NLO properties of novel cationic cyclometallated Ir(III) complexes of the type $\left[\operatorname{Ir}(2 \text {-phenylpyridine })_{2}(9-\mathrm{R}-4,5 \text {-diazafluorene })\right]^{+}(\mathrm{R}=\mathrm{H}$, fulleridene $)$ and the related neutral complex with the new 9-fulleriden-4-monoazafluorene ligand. Inorg. Chim. Acta 2012, 382, 72-78.

36. Hierlinger, C.; Cordes, D.B.; Slawin, A.M.Z.; Colombo, A.; Dragonetti, C.; Righetto, S.; Roberto, D.; Jacquemin, D.; Zysman-Colman, E.; Guerchais, V. An investigation on the second-order nonlinear optical response of cationic bipyridine or phenanthroline iridium(III) complexes bearing cyclometallated 2-phenylpyridines with a triphenylamine substituent. Dalton Trans. 2018, 47, 8292-8300. [CrossRef] [PubMed]

37. Wang, H.-Y.; Jing, L.-X.; Wang, H.-Q.; Ye, J.-T.; Qiu, Y.-Q. Improving the NLO response of bis-cyclometalated iridium(III) complexes by modifying ligands: A DFT study. J. Organomet. Chem. 2018, 869, 18-25. [CrossRef]

38. Bolink, H.J.; Cappelli, E.; Coronado, E.; Graetzel, M.; Orti, E.; Costa, R.D.; Viruela, P.M.; Nazeeruddin, K. Stable single-layer light-emitting electrochemical cell using 4,7-diphenyl-1,10-phenanthroline-bis(2-phenylpyridine) iridium (III) hexafluorophosphate. J. Am. Chem. Soc. 2006, 128, 14786-14787. [CrossRef] [PubMed]

39. Margapoti, E.; Shukla, V.; Valore, A.; Sharma, A.; Dragonetti, C.; Kitts, C.C.; Roberto, D.; Murgia, M.; Ugo, R.; Muccini, M. Excimer Emission in Single Layer Electroluminescent Devices Based on $\left[\operatorname{Ir}(4,5-\text { diphenyl-2-methylthiazolo })_{2} \text { (5-methyl-1,10-phenanthroline) }\right]^{+}\left[\mathrm{PF}_{6}\right]^{-}$. J. Phys. Chem. C 2009, 113, 12517-12522. [CrossRef]

40. Ma, D.; Tsuboi, T.; Qiu, Y.; Duan, L. Recent Progress in Ionic Iridium(III) complexes for organic electronic devices. Adv. Mater. 2017, 29, 1603253. [CrossRef]

41. Zysman-Colman, E. Iridium(III) in Optoelectronic and Photonics Applications; John Wiley \& Sons Ltd.: Hoboken, NJ, USA, 2017.

42. Dragonetti, C.; Valore, A.; Colombo, A.; Righetto, S.; Trifiletti, V. Simple novel cyclometallated iridium complexes for potential application in dye-sensitized solar cells. Inorg. Chim. Acta 2012, 388, 163-167. [CrossRef]

43. Dragonetti, C.; Colombo, A.; Magni, M.; Mussini, P.; Nisic, F.; Roberto, D.; Ugo, R.; Valore, A.; Valsecchi, A.; Salvatori, P.; et al. Thiocyanate-Free Ruthenium(II) Sensitizer with a Pyrid-2-yltetrazolate ligand for dye-sensitized solar cells. Inorg. Chem. 2013, 52, 10723-10725. [CrossRef]

44. Hierlinger, C.; Flint, H.V.; Cordes, D.B.; Slawin, A.M.Z.; Gibson, E.A.; Jacquemin, D.; Guerchais, V.; Zysman-Colman, E. A panchromatic, near infrared $\operatorname{Ir}(\mathrm{III})$ emitter bearing a tripodal $\mathrm{C}^{\wedge} \mathrm{N}^{\wedge} \mathrm{C}$ ligand as a dye for dye-sensitized solar cells. Polyhedron 2018, 140, 109-115. [CrossRef]

45. Légalité, F.; Escudero, D.; Pellegrin, Y.; Blart, E.; Jacquemin, D.; Odobel, F. “Iridium effect" in cyclometalated iridium complexes for p-type dye sensitized solar cells. Dyes Pigment. 2019, 171, 107693. [CrossRef] 
46. Jin, C.; Liu, J.; Chen, Y.; Zeng, L.; Guan, R.; Ouyang, C.; Ji, L.; Chao, H. Cyclometalated Iridium (III) complexes as two-photon phosphorescent probes for specific mitochondrial dynamics tracking in living cells. Chem. Eur. J. 2015, 21, 12000-12010. [CrossRef]

47. Colombo, A.; Dragonetti, C.; Roberto, D.; Valore, A.; Ferrante, C.; Fortunati, I.; Picone, A.L.; Todescato, F.; Williams, J.A.G. Two-photon absorption properties and ${ }^{1} \mathrm{O}_{2}$ generation ability of Ir complexes: Unexpected large cross section of $\left[\operatorname{Ir}(\mathrm{CO})_{2} \mathrm{Cl}(4\right.$-(para-di-N-butylaminostyryl)pyridine)]. Dalton Trans. 2015, 44, 15712-15720. [CrossRef] [PubMed]

48. Sun, L.; Chen, Y.; Kuang, S.; Li, G.; Guan, R.; Liu, J.; Ji, L.; Chao, H. Iridium (III) anthraquinone complexes as two-photon phosphorescence probes for mitochondria imaging and tracking under hypoxia. Chem. Eur. J. 2016, 22, 8955-8965. [CrossRef]

49. Lepeltier, M.; Appaix, F.; Liao, Y.Y.; Dumur, F.; Marrot, J.; Le Bahers, T.; Andraud, C.; Monnereau, C. Carbazole-substituted iridium complex as a solid state emitter for two-photon intravital imaging. Inorg. Chem. 2016, 55, 9586-9595. [CrossRef] [PubMed]

50. Colombo, A.; Garoni, E.; Dragonetti, C.; Righetto, S.; Roberto, D.; Baggi, N.; Escadeillas, M.; Guerchais, V.; Kamada, K. A novel multifunctional cyclometallated iridium(III) complex with interesting second-order nonlinear optical properties and two-photon absorption activity. Polyhedron 2018, 140, 116-121. [CrossRef]

51. Murphy, L.; Congreve, A.; Palsson, L.-O.; Williams, J.A.G. The time domain in co-stained cell imaging: Time-resolved emission imaging microscopy using a protonatable luminescent iridium complex. Chem Commun. 2010, 46, 8743-8745. [CrossRef] [PubMed]

52. Steunenberg, P.; Ruggi, A.; van den Berg, N.S.; Buckle, T.; Kuil, J.; van Leeuwen, F.W.V.; Velders, A.H. Phosphorescence imaging of living cells with amino acid-functionalized Tris(2-phenylpyridine)iridium(III) Complexes. Inorg. Chem. 2012, 51, 2105-2114. [CrossRef]

53. Day, A.H.; Übler, M.H.; Best, H.L.; Lloyd-Evans, E.; Mart, R.J.; Fallis, I.A.; Allemann, R.K.; Al-Wattar, E.A.H.; Keymer, N.I.; Buurma, N.J.; et al. Targeted cell imaging properties of a deep red luminescent iridium(III) complex conjugated with a c-Myc signal peptide. Chem. Sci. 2020, 11, 1599-1606. [CrossRef]

54. Colombo, A.; Fontani, M.; Dragonetti, C.; Roberto, D.; Williams, J.A.G.; Scotto di Perrotolo, R.; Casagrande, F.; Barozzi, S.; Polo, S. A highly luminescent tetrahydrocurcumin Ir(III) complex with remarkable photoactivated anticancer activity. Chem. Eur. J. 2019, 25, 7948-7952. [CrossRef]

55. Chen, H.; Ge, C.; Cao, H.; Zhang, X.; Zhang, L.; Jiang, L.; Zhang, P.; Zhang, Q. Isomeric Ir(III) complexes for tracking mitochondrial $\mathrm{pH}$ fluctuations and inducing mitochondrial dysfunction during photodynamic therapy. Dalton Trans. 2019, 48, 17200-17209. [CrossRef]

56. McKenzie, L.K.; Sazanovich, I.V.; Baggaley, E.; Bonneau, M.; Guerchais, V.; Williams, J.A.G.; Weinstein, J.A.; Bryant, H.E. Metal complexes for two-photon photodynamic therapy: A cyclometallated iridium complex induces two-photon photosensitization of cancer cells under near-IR light. Chem. Eur. J. 2017, 23, $234-238$. [CrossRef]

57. McKenzie, L.K.; Bryant, H.E.; Weinstein, J.A. Transition metal complexes as photosensitisers in one- and two-photon photodynamic therapy. Coord. Chem. Rev. 2019, 379, 2-29. [CrossRef]

58. Aubert, V.; Ordronneau, L.; Escadeillas, M.; Williams, J.A.G.; Boucekkine, A.; Coulaud, E.; Dragonetti, C.; Righetto, S.; Roberto, D.; Ugo, R.; et al. Linear and nonlinear optical properties of cationic bipyridyl iridium(III) complexes: Tunable and photoswitchable? Inorg. Chem. 2011, 50, 5027-5038. [CrossRef] [PubMed]

59. Zaarour, M.; Singh, A.; Latouche, C.; Williams, J.A.G.; Ledoux-Rak, I.; Zyss, J.; Boucekkine, A.; Le Bozec, H.; Guerchais, V.; Dragonetti, C.; et al. Linear and nonlinear optical properties of tris-cyclometalated phenylpyridine $\operatorname{Ir}(\mathrm{III})$ complexes incorporating $\pi$-conjugated substituents. Inorg. Chem. 2013, 52, 7987-7994. [CrossRef]

60. Wang, J.; Wang, W.-Y.; Fang, X.-Y.; Qiu, Y.-Q. Carborane tuning on iridium complexes: Redox-switchable second-order NLO responses. J. Mol. Model. 2015, 21, 95. [CrossRef]

61. Li, X.; Wang, H.-Q.; Ye, J.-T.; Zhang, Y.; Qiu, Y.-Q. Second-order NLO properties of bis-cyclometalated iridium(III) complexes: Substituent effect and redox switch. J. Mol. Graph. Model. 2019, 89, 131-138. [CrossRef]

62. Edkins, R.M.; Bettington, S.L.; Goeta, A.E.; Beeby, A. Two-photon spectroscopy of cyclometalated iridium complexes. Dalton Trans. 2011, 40, 12765-12770. [CrossRef] 
63. Valore, A.; Colombo, A.; Dragonetti, C.; Righetto, S.; Roberto, D.; Ugo, R.; De Angelis, F.; Fantacci, S. Luminescent cyclometallated $\mathrm{Ir}(\mathrm{III})$ and $\mathrm{Pt}(\mathrm{II})$ complexes with $\beta$-diketonate ligands as highly active second-order NLO chromophores. Chem. Commun. 2010, 46, 2414-2416. [CrossRef]

64. Dragonetti, C.; Colombo, A.; Marinotto, D.; Righetto, S.; Roberto, D.; Valore, A.; Escadeillas, M.; Guerchais, V.; Le Bozec, H.; Boucekkine, A.; et al. Functionalized styryl Iridium(III) complexes as active second-order NLO chromophores and building blocks for SHG polymeric films. J. Organomet. Chem. 2014, 751, 568-572. [CrossRef]

65. Sprouse, S.; King, K.A.; Spellane, P.J.; Watts, R.J. Photophysical effects of metal-carbon bonds in ortho-metalated complexes of Ir(III) and Rh(III). J. Am. Chem. Soc. 1984, 106, 6647-6653. [CrossRef]

66. Oudar, J.L.; Chemla, D.S. Hyperpolarizabilities of the nitroanilines and their relations to the excited state dipole moment. J. Chem. Phys. 1977, 66, 2664-2668. [CrossRef]

67. Oudar, J.L. Optical nonlinearities of conjugated molecules. Stilbene derivatives and highly polar aromatic compounds. J. Chem. Phys. 1977, 67, 446-457. [CrossRef]

68. Cariati, E.; Roberto, D.; Ugo, R.; Ford, P.C.; Galli, S.; Sironi, A. X-ray structures and emissive and second-order nonlinear optical properties of two inorganic-organic polymeric adducts of $\mathrm{CuI}$ with 4-acetylpyridine. The role of both "Intrastrand" charge transfers and structural motifs on the nonlinear optical response of $\mathrm{Cu}(\mathrm{I})$ polymeric adducts with pseudoaromatic $\eta 1$-nitrogen donor ligands. Chem. Mater. 2002, 14, 5116-5123.

69. Barsu, C.; Fortrie, R.; Nowika, K.; Baldeck, P.L.; Vial, J.C.; Barsella, A.; Fort, A.; Hissler, M.; Bretonnière, Y.; Maury, O.; et al. Synthesis of chromophores combining second harmonic generation and two photon induced fluorescence properties. Chem. Commun. 2006, 4744-4746. [CrossRef] [PubMed]

70. Todescato, F.; Fortunati, I.; Carlotto, S.; Ferrante, C.; Grisanti, L.; Sissa, C.; Painelli, A.; Colombo, A.; Dragonetti, C.; Roberto, D. Dimers of polar chromophores in solution: Role of excitonic interactions in oneand two-photon absorption properties. Phys. Chem. Chem. Phys. 2011, 13, 11099-11109. [CrossRef] [PubMed]

71. Ka Man Chan, C.; Tao, C.-H.; Li, K.-F.; Wong, K.M.-C.; Zhu, N.; Cheah, K.-W.; Yam, V.W.-W. Synthesis, characterization, luminescence and nonlinear optical (NLO) properties of truxene-containing platinum(II) alkynyl complexes. J. Organomet. Chem. 2011, 696, 1163-1173. [CrossRef]

72. Rossi, E.; Colombo, A.; Dragonetti, C.; Righetto, S.; Roberto, D.; Ugo, R.; Valore, A.; Williams, J.A.G.; Lobello, M.G.; De Angelis, F; et al. Tuning the dipolar second-order nonlinear optical properties of cyclometalated platinum(II) complexes with tridentate $\mathrm{N}^{\wedge} \mathrm{C}^{\wedge} \mathrm{N}$ binding ligands. Chem. Eur. J. 2013, 19, 9875-9883. [CrossRef]

73. Chavan, S.S.; Pawal, S.B.; Lolage, S.R.; Garadkar, K.M. Synthesis, spectroscopic characterization, luminescence and NLO properties of heterometallic $\mathrm{M}(\mathrm{II})-\mathrm{Ru}(\mathrm{II})(\mathrm{M}=\mathrm{Ni}$ and $\mathrm{Zn}$ ) hybrid complexes composed of coordination and organometallic sites. J. Organomet. Chem. 2017, 853, 18-26. [CrossRef]

74. Guerchais, V.; Boixel, J.; Le Bozec, H. Linear and nonlinear optical molecular switches based on photochromic metal complexes. In Photon-Working Switches; Yokoyama, Y., Nakatani, K., Eds.; Springer: Tokyo, Japan, 2017; pp. 363-384.

75. Zhao, H.; Garoni, E.; Roisnel, T.; Colombo, A.; Dragonetti, C.; Marinotto, D.; Righetto, S.; Roberto, D.; Jacquemin, D.; Boixel, J.; et al. Photochromic DTE-Substituted-1,3-di(2-pyridyl)benzene Platinum(II) Complexes: Photomodulation of luminescence and second-order nonlinear optical properties. Inorg. Chem. 2018, 57, 7051-7063. [CrossRef]

76. Chakrabarty, R.; Dutta, A.; Roy, S.; Das, G.; Ledoux-Rak, I.; Mondal, P.; Prasad, S.K.; Rao, D.S.S.; Bhattacharjee, C.R. Multifunctional lanthanide complexes: Mesomorphism, photoluminescence and second order NLO property. Chem. Sel. 2018, 3, 8245-8251. [CrossRef]

77. Matozzo, P.; Colombo, A.; Dragonetti, C.; Righetto, S.; Roberto, D.; Biagini, P.; Fantacci, S.; Marinotto, D. A known chiral bis(salicylaldiminato)zinc(II) complex with unexpected interesting second-order nonlinear optical and luminescent properties in solution. Inorganics 2020, 8, 25. [CrossRef]

78. Page, R.H.; Jurich, M.C.; Beck, B.; Sen, A.; Twieg, R.J.; Swalen, J.D.; Bjorklund, G.C.; Wilson, C.G. Electrochromic and optical waveguide studies of corona-poled electro-optic polymer films. J. Opt. Soc. Am. B 1990, 7, 1239-1250. [CrossRef]

79. Herman, W.N.; Hayden, L.M. Maker fringes revisited: Second-harmonic generation from birefringent or absorbing materials. J. Opt. Soc. Am. B 1995, 12, 416-427. [CrossRef] 
80. Macchi, R.; Cariati, E.; Marinotto, D.; Roberto, D.; Tordin, E.; Ugo, R.; Bozio, R.; Cozzuol, M.; Pedron, D.; Mattei, G. Stable SHG from in situ grown oriented nanocrystals of [(E)-N,N-dimethylamino- $N$ '-methylstilbazolium][ $p$-toluenesulfonate] in a PMMA film. J. Mater. Chem. 2010, 20, 1885-1890. [CrossRef]

81. Roberto, D.; Colombo, A.; Dragonetti, C.; Marinotto, D.; Righetto, S.; Tavazzi, S.; Escadeillas, M.; Guerchais, V.; Le Bozec, H.; Boucekkine, A.; et al. Cyclometallated 4-styryl-2-phenylpyridine Pt(II) acetylacetonate complexes as second-order NLO building blocks for SHG active polymeric films. Organometallics 2013, 32, 3890-3894.

82. Colombo, A.; Nisic, F.; Dragonetti, C.; Marinotto, D.; Oliveri, I.P.; Righetto, S.; Lobello, M.G.; De Angelis, F. Unexpectedly high second-order nonlinear optical properties of simple Ru and Pt alkynyl complexes as an analytical springboard for NLO-active polymer films. Chem. Commun. 2014, 50, 7986-7989. [CrossRef]

83. Prabu, S.; David, E.; Viswanathan, T.; Thirumoorthy, K.; Panda, T.; Dragonetti, C.; Colombo, A.; Marinotto, D.; Righetto, S.; Roberto, D.; et al. NLO-active Y-shaped ferrocene conjugated imidazole chromophores as precursors for SHG polymeric films. Dalton Trans. 2020, 49, 1854-1863. [CrossRef]

(C) 2020 by the authors. Licensee MDPI, Basel, Switzerland. This article is an open access article distributed under the terms and conditions of the Creative Commons Attribution (CC BY) license (http://creativecommons.org/licenses/by/4.0/). 